\title{
Аналіз енергетичних перспектив охолодження природного газу в магістральних газопроводах за допомогою абсорбційних холодиль- них машин
}

\author{
О. С. Тітлов ${ }^{\varpi 1}$, І. Л. Бошкова ${ }^{2}$ В. М. Дорошенко \\ ${ }^{1-6}$ Одеська національна академія харчових технологій, вул. Канатна, 112, Одеса, 65039, Україна \\ $\triangle$ e-mail: ${ }^{1}$ titlov1959@gmail.com \\ ORCID: ${ }^{1}$ https://orcid.org/0000-0003-1908-5713; ${ }^{2}$ https://orcid.org/0000-0001-5989-9223; \\ ${ }^{3}$ https://orcid.org/0000-0003-3408-6124; ${ }^{4}$ https://orcid.org/0000-0003-1908-5713; \\ ${ }^{5}$ https://orcid.org/0000-0003-3569-7920; ${ }^{6}$ https://orcid.org/0000-0001-5923-2584
}

\begin{abstract}
Для транспортування природного газу магістральними трубопроводами на компресорних станиіях (КС) встановлені газоперекачувальні агрегати (ГПА), енергоносієм для яких, в більшості випадків, $\epsilon$ природний газ, щя транспортується. На привід ГПА витрачається (спалюється) 0,5...1,5 \% від обсягу газу, що транспортується. Для поточної економічної ситуачії на ринку газу України добове зниження експлуатаційних витрат у типових магістральних газопроводах при зниженні температури газу перед стисненням у ГПА на 20 К становить від 1800 до 3360 \$. Одним з перспективних напрямків зниження експлуатаційних втрат у магістральних газопроводах є попереднє охолодження компримованого газу за допомогою тепловикористальних абсорбиійних холодильних машин (АХМ), які утилізують скидне тепло відпрацьованих продуктів згоряння газоперекачувальних агрегатів. Відповідно до розробленого алгоритму було виконано розрахунок нагнітача для різних температур природного газу перед компримуванням. Показано, що використання типового магістрального газопроводу штучного охолодження потоку газу перед всмоктуванням дасть економію витрати паливного газу 79 кг/год. Виконано термодинамічний розрахунок ичиклів АХМ різного типу. Показано, що незважаючи на більш високий тепловий коефіцієнт у бромістолітієвих АХМ $(0,808)$, слід вибрати водоаміачні АХМ з тепловим коефічієнтом 0,477, тому що тільки водоаміачні АХМ можуть забезпечити прийнятний рівень температур охолодження (258 K) природного газу перед компримуванням, на відміну від бромістолітієвих АХМ з температурою охолодження не вище $280 \mathrm{~K}$. Виконано конструкторський (тепловий) розрахунок теплообмінника-охолоджувача (ТОО) природного газу перед стисненням у нагнітачі. Проведено розрахунок конструкиії теплообмінника з коаксіальним розташуванням ребер з боку газового потоку. Матеріал ребер - алюміній.
\end{abstract}

Ключові слова: Абсорбиійні холодильні машини; Скидне тепло; Енергетична ефективність; Компресорні станиії; Попередне охолодження природного газу; Магістральні газопроводи

\section{doi: https://doi.org/10.15673/ret.v57i3.2165}

(C) The Author(s) 2021. This article is an open access publication

This work is licensed under the Creative Commons Attribution 4.0 International License (CC BY)

http://creativecommons.org/licenses/by/4.0/

\section{1. Вступ}

Газотранспортна система України призначена для подавання газу як внутрішнім споживачам, так і транзиту палива до країн Західної Свропи. Для транспортування природного газу магістральними трубопроводами на компресорних станціях (КС) встановлені газоперекачувальні агрегати (ГПА), 
енергоносієм для яких, в більшості випадків, є природний газ, що транспортується. На привід ГПА витрачається (спалюється) 0,5...1,5 \% від обсягу газу, що транспортується [1].

Проведений аналіз шляхів підвищення енергетичної ефективності ГПА [2] показав, що одним 3 перспективних напрямків, може бути застосування попереднього охолодження газу, що компримується, за допомогою тепловикористальних абсорбційних водоаміачних холодильних машин (АВХМ), які утилізують скидне тепло відпрацьованих продуктів згоряння [3, 4].

Було показано [2], що для поточної економічної ситуації (липень 2019 року) на ринку газу України добове зниження експлуатаційних витрат у типових магістральних газопроводах при зниженні температури газу перед стисненням у ГПА на 20 К становить від 1800 до 3360\$.
Так як транспортування газу здійснюється цілорічно у різних кліматичних (температурних) умовах навколишнього середовища, необхідно провести оцінку в змінах енергетичної ефективності циклу АВХМ.

Особливий інтерес становлять також занижені температури об'єкта охолодження, які дозволяють підвищити корисний ефект попереднього охолодження природного газу перед стисненням [2]

\section{2. Характеристики нагнітача}

У якості вхідних параметрів приймемо дані, що використовуються на кафедрі нафтогазових технологій, інженерії та теплоенергетики ОНАХТ для розрахунку магістрального трубопроводу.

На рис.1 представлена умовна схема магістрального газопроводу з проміжними КС.

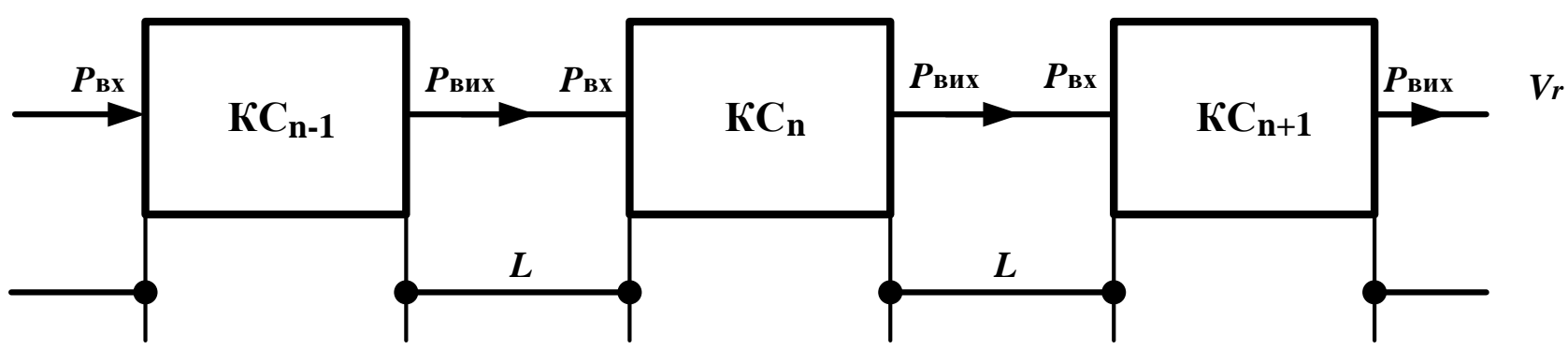

Рисунок 1 - Умовна схема магістрального газопроводу (КС - проміжні компресорні станціі)

Діаметр магістрального трубопроводу - 1200 мм;

Привід нагнітач - газотурбінний двигун (ГТД) типу ДН-70 [19];

Номінальна потужність на валу ГТД - 10 МВт;

Кількість паралельно працюючих нагнітачів $3+1$ (один у резерві);

Тиск газу на виході з компресорної станції $p_{\text {наг }}=7,4 \mathrm{MПа;}$

Тиск газу на вході до компресорної станції $p_{\mathrm{Bc}}=6,0 \mathrm{M \Pi а}$;

Відстань між КС - 120 км;

Температура грунту $-T_{\mathrm{rp}}=14{ }^{\circ} \mathrm{C}=287 \mathrm{~K}$;

Розрахункова температура навколишнього повітря влітку $-T_{\text {нс }}=25^{\circ} \mathrm{C}=298 \mathrm{~K}$;

Комерційна витрата газу за його температури $Q_{\text {КС }}=52,07$ млн. м ${ }^{3} /$ добу;

Витрата паливного газу одного ДН-70 за номінального режиму - 2098 кг/год;

Густина природного газу за нормальних умов $\left(0{ }^{\circ} \mathrm{C}\right.$ та $\left.0,1013 \mathrm{MПа}\right)-\rho=0,719 \kappa \Gamma / \mathrm{m}^{3} ;$

Псевдокритична температура $-T_{\text {пк }}=192,7 \mathrm{~K}$;

Псевдокритичний тиск $-p_{\text {пк }}=4,73 \mathrm{MПа;}$
Індивідуальна газова постійна $-R=516,2$ Дж/(кг К).

Характеристики нагнітача (компресора) природного газу типу Н-300-1,23 наведено на рис. 2.

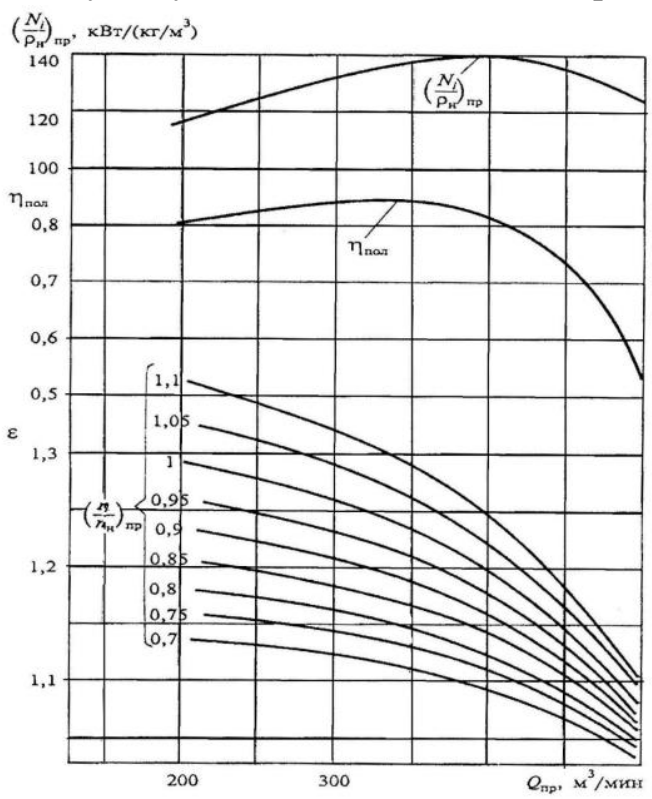

Рисунок 2 - Наведені характеристики нагнітача при $T_{\text {нав }}=288 K ; Z_{\text {нав }}=0,91 ; R_{\text {нав }}=490$ Джс/(кг K) 
Довідкові характеристики газотурбінного двигуна ДН-70:

- Номінальна потужність на валу вільної турбіни - 10500 кВт;

- Ступінь підвищення повного тиску повітря в осьовому компресорі - 19,5;

- Витрата продуктів згоряння на вихлопі 36,8 кг/с;

- Розрахункова температура газу на зрізі вихлопного патрубка в літній період $-550{ }^{\circ} \mathrm{C}$;

- Розрахункова температура газу на зрізі вихлопного патрубка в зимовий період $-430^{\circ} \mathrm{C}$;

- Номінальна частота обертання ротора турбіни - 3000, 3600, 4800, 6500 об/хв;

- Тиск паливного газу - $3 \mathrm{MПа;}$

- Витрата паливного газу на номінальному режимі - 2098 кг/год;

- Відносне зниження ККД ГТД за міжремонтний період - $2 \%$;

- Час пуску та навантаження на холостому ході-3 xв;

- Час набору повного навантаження - 25 хв;

- Ресурс газогенератора до капітального ремонту - 25000 год;

- Ресурс модуля силової турбіни до капітального ремонту - 25000 год;

- Повний ресурс ГТД - 100000 год;

- Маса блоку ГТД - 18500 кг.

Схема нагнітача Н-300-1,23 наведена на рис. 3.

Розрахунок проводимо для 4-х рівнів температур газу на всмоктуванні: $T_{\text {вс }}=285 ; 292,5 ; 300 \mathrm{~K}$.

Вважаємо, що тиски всмоктування та нагнітання залишаються незмінними у всьому діапазоні розрахункових температур всмоктування, тобто:

$$
P_{\Pi P}=\frac{6,0}{4,73}=1,268
$$

а ступінь стиснення газу

$$
\varepsilon=\frac{7,4}{6,0}=1,23
$$

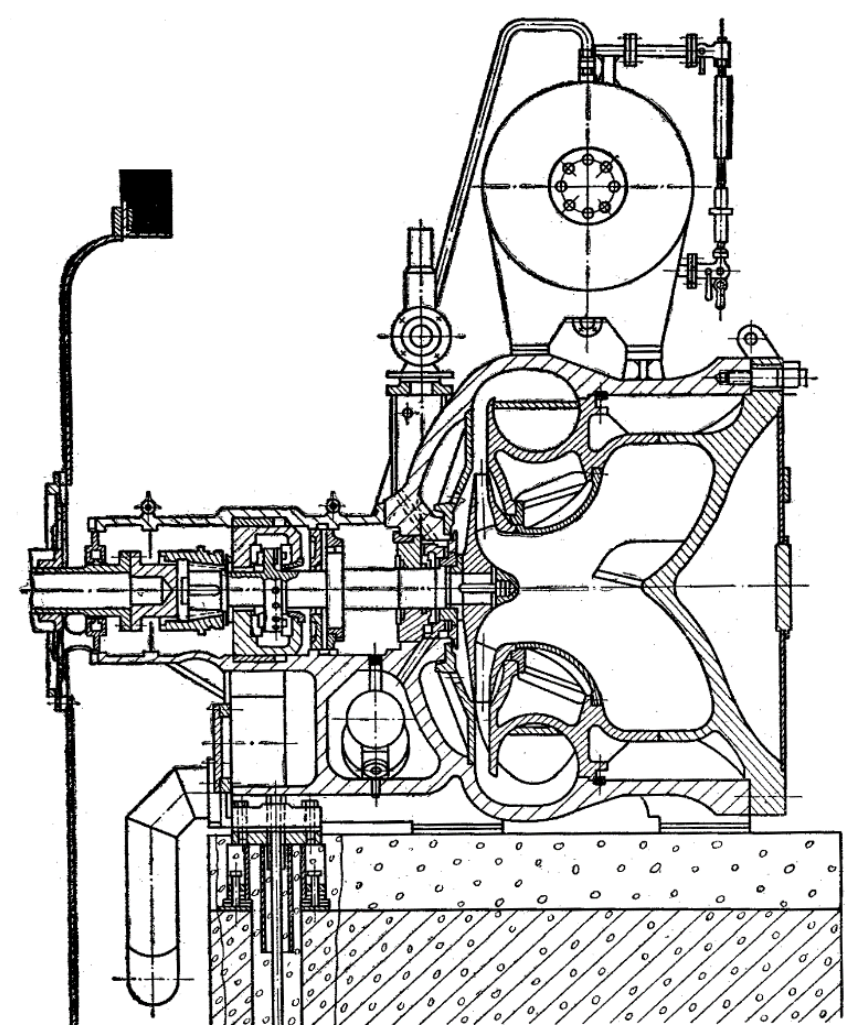

Рисунок 3 - Схема нагнітача H-300-1,23

Результати розрахунків зводимо до таблиці 1.

\begin{tabular}{|c|c|c|c|c|}
\hline \multirow{2}{*}{ Найменування параметра/ характеристики } & \multicolumn{4}{|c|}{ Температура на всмоктуванні $T_{\text {вс }}, \mathrm{K}$} \\
\hline & 275 & 285 & 292,5 & 300 \\
\hline Наведена температура $T_{\text {нав}}, \mathrm{K}$ & 1,427 & 1,479 & 1,518 & 1,557 \\
\hline Коефіцієнт стисливотсі $Z_{\text {вс }}$ & 0,862 & 0,881 & 0,893 & 0,903 \\
\hline Комплекс $\tau$ & 0,222 & 0,256 & 0,295 & 0,316 \\
\hline Густина газу на всмоктуванні $\rho_{\text {вс }}, \kappa \Gamma / \mathrm{M}^{3}$ & 52,60 & 49,70 & 47,77 & 46,05 \\
\hline $\begin{array}{l}\text { Наведена обємна витрата газу на всмоктуванні } \\
Q_{\text {пр }}, \text { м }^{3} / \text { хв }\end{array}$ & 215 & 210 & 200 & 190 \\
\hline ККД нагнітача $\eta_{\text {пол }}$ (див. рис. 2) & 0,81 & 0,81 & 0,80 & 0,78 \\
\hline Комплекс $\left[N_{\mathrm{i}} / \rho_{\mathrm{H}}\right]_{\text {нав }}, \kappa \mathrm{BT} /\left(\kappa \Gamma / \mathrm{M}^{3}\right)$ & 119 & 119 & 118 & 116 \\
\hline $\begin{array}{l}\text { Фактична частота обертання ротору нагнітача } \\
n_{\mathrm{H}}, 1 / \text { хв }\end{array}$ & 5177 & 5301 & 5566 & 5859 \\
\hline $\begin{array}{l}\text { Внутрішня потужність, що споживається нагні- } \\
\text { тачем } N_{i}, \text { кВт }\end{array}$ & 3733 & 3787 & 4179 & 4698 \\
\hline Температура кінця стиснення $T_{\text {наг }}, \mathrm{K}$ & 291 & 302 & 310,5 & 319 \\
\hline
\end{tabular}

Таблиця 1 - Результати розрахунку робочих параметрів нагнітача газу 
Для нагнітача Н-300-1,23 номінальна витрата $Q_{\mathrm{H}}=19,0$ млн. м³/добу. Тоді кількість нагнітачів:

$$
\begin{gathered}
m_{\mathrm{H}}=\frac{Q_{\mathrm{KC}} / Q_{\mathrm{H}}}{} \\
m_{\mathrm{H}}=52,07 / 19,0 \approx 3 \text { шт. }
\end{gathered}
$$

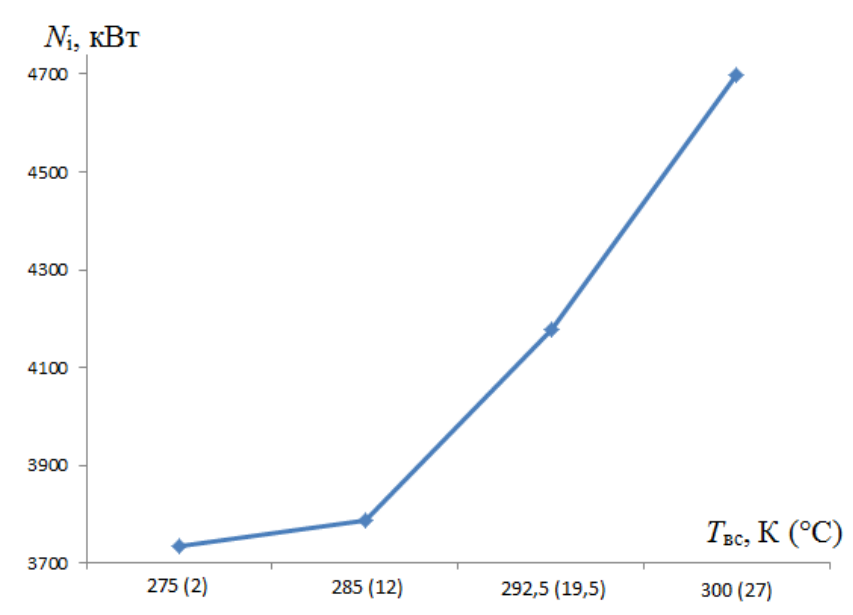

Рисунок 4-Залежність індикаторної потужності нагнітача від чисельного значення температури природного газу на всмоктуванні

3 довідкових характеристик газотурбінного двигуна ДН-70 випливає, що у номінальному режимі на 1 кВт потужності на валу турбіни припадає 0,2 кг/год паливного газу.

Не маючи відомостей про витрату паливного газу у відмінних від номінального режиму умовах, приймемо його постійним.

Тоді залежність витрати паливного газу від температури всмоктування якісно матиме вигляд аналогічний рис. 4 , тобто при $T_{\mathrm{Bc}}=285 ; 292,5 ; 300 \mathrm{~K}$ витрата паливного газу відповідно становитиме 747; 757; 836; 940 кг/год.

Вважатимемо рівень температур на всмоктуванні $285 \mathrm{~K}\left(12{ }^{\circ} \mathrm{C}\right)$ реально досяжним за допомогою $\mathrm{ABXM} 3$ досить високим температурним натиском між потоками газу та розсолу. Приймемо за базовий режим $T_{\mathrm{Bc}}=292,5 \mathrm{~K}\left(19,5{ }^{\circ} \mathrm{C}\right)$, при якій нагнітач працює тривалий час на рік.

Використання штучного охолодження потоку газу перед всмоктуванням дасть економію витрати паливного газу: $836-757=79$ кг/год.

$\mathrm{У}$ стандартних умовах при $\rho=0,719 \kappa \Gamma / \mathrm{m}^{3}$ об'ємна витрата зекономленого паливного газу складе: 79/0,719 $=109,875 \mathrm{~m}^{3} /$ год.

\section{3. Розрахунок АБХМ}

Проведемо розрахунок теплових потоків бро-
Об'ємна витрата газу на всмоктуванні також у всіх випадках однакова: $Q_{\text {вс }}=181 \mathrm{~m}^{3} /$ хв.

Номінальна частота обертання ротору нагнітача $n_{\mathrm{H}}=6150$ об $/$ хв.

Результати розрахунків наведені у вигляді графічних залежностей на рис. 4 i рис.5.

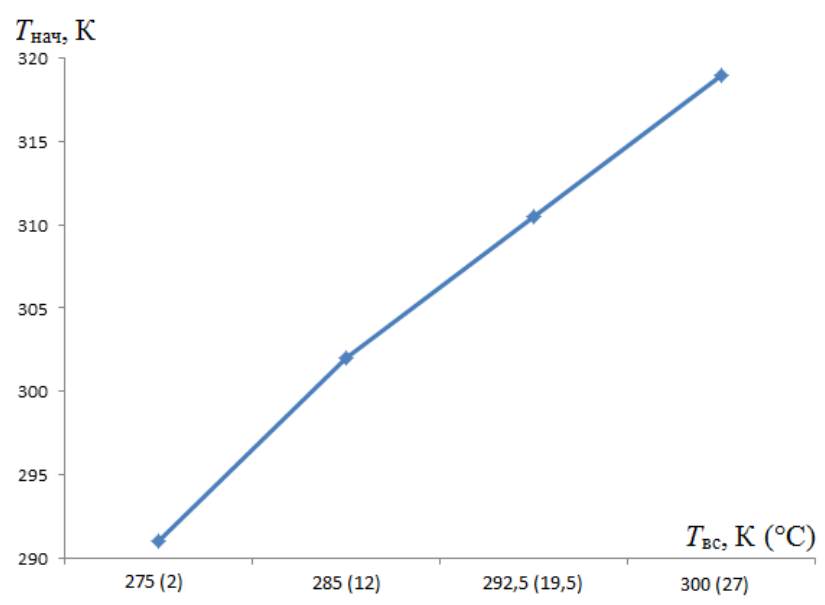

Рисунок 5 - Залежність початкової температури нагнітача від чисельного значення темпера-

тури природного газу на всмоктуванні

містолітієвої абсорбційної холодильної машини (рис.6) без урахування основних незворотних втрат термодинамічних процесів [5].

Початкові дані:

- Температура гріючої води $T_{h}=373 \mathrm{~K}$.

- Охолоджуючої води $T_{w}=299 \mathrm{~K}$.

- Охолодженої води $T_{s}=280 \mathrm{~K}$.

Прийняті значення температур та тисків наступні. Найвища температура в кінці процесу кипіння розчину в генераторі $T_{4}=T_{h}-\Delta T$.

Різниця температур $\Delta T_{h}=10 \ldots 20 \mathrm{~K}$, залежно від типу генератора. Тоді $T_{4}=273-15=258 \mathrm{~K}$. Температура конденсації за умови паралельного подавання води в абсорбер та конденсатор $T_{\mathrm{K}}=T_{w}+\Delta T_{w}$.

Різниця температур $\Delta T_{w}=8 \ldots 10 \mathrm{~K}$. Тоді $T_{\mathrm{K}}=299+8=307 \mathrm{~K}$.

Тиск конденсації пари в конденсаторі визначають за діаграмою концентрація-ентальпія $(\xi-i)$ для водного розчину бромістого літію [6] в області рідини при $\xi=0$ і $T_{\mathrm{\kappa}}=307 \mathrm{~K}: p_{\mathrm{\kappa}}=5,45$ кПа.

За відсутності гідравлічних опорів проходження пари з генератора в конденсатор, тиск кипіння розчину в генераторі приймається рівним тиску конденсатора, тобто $p_{h}=p_{\text {к }}=5,45$ кПа.

Нижча температура розчину в кінці процесу абсорбції пари в абсорбері $T_{2}=T_{w}+\Delta T_{a}$. Різниця температур $\Delta T_{a}=8 \ldots 15 \mathrm{~K}$. Тоді $T_{2}=299+8=307 \mathrm{~K}$. 


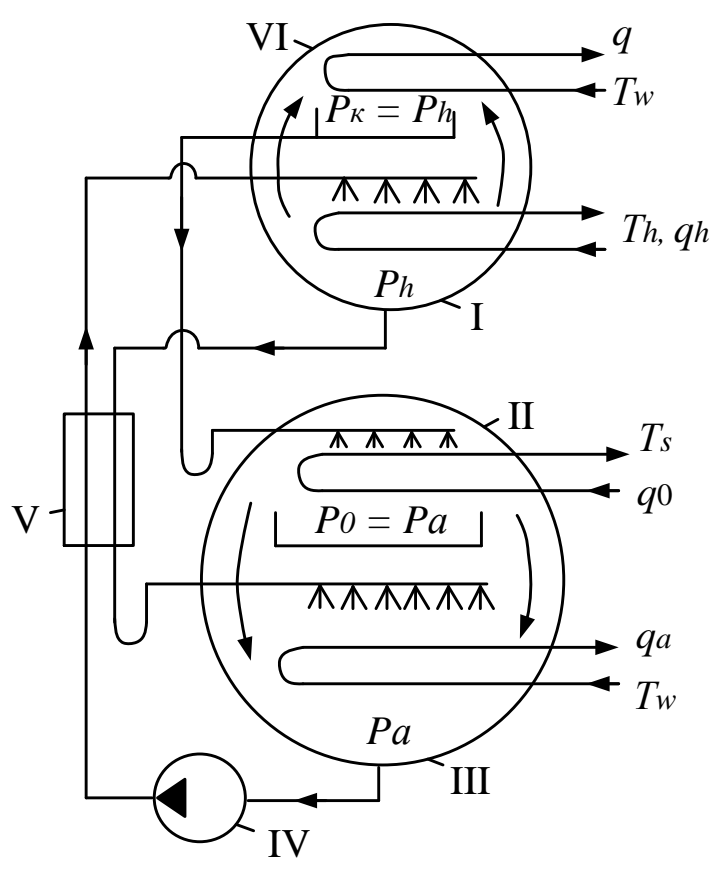

a)

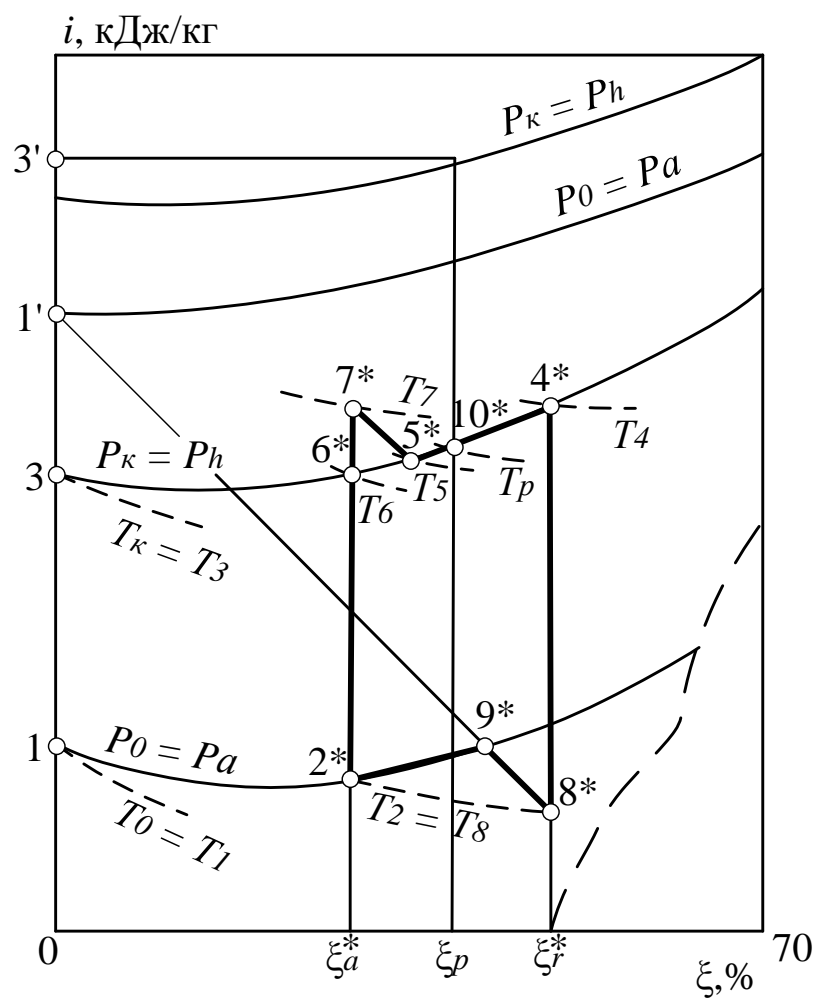

б)

Рисунок 6 - Абсорбиійна бромістолітієва холодильна машина:

а-схема машини; б - прочеси в $\xi$-і діаграмі; I - генератор; II- випарник; III-абсорбер; IV - насос слабкого розчину; V- теплообмінник; VI-конденсатор

Температура кипіння води у випарнику $T_{0}=T_{s}-\Delta T_{s}$. Різниця температур $\Delta T_{s}$ приймається не більше $2 \ldots . .5$ К. Тоді $T_{0}=280-3=277 \mathrm{~K}$.

Тиск кипіння у випарнику визначають за таблицями теплофізичних властивостей води та водяної пари або по $\xi-i$ діаграмі (при $\xi=0$ і $T_{0}=277 \mathrm{~K}$ ) [17]: $p_{0}=0,83$ кПа.

За відсутності гідравлічних опорів проходження пари з випарника в абсорбер, тиск в абсорбері приймається рівним тиску у випарнику, тобто $p_{\mathrm{a}}=p_{0}=0,83$ кПа.

Температура міцного розчину на виході $з$ теплообмінника за відсутності в ньому недорекуперації теплоти $T_{8}=T_{2}=307 \mathrm{~K}$.

Параметри вузлових точок циклів, зображених на рис. 6а, наведені в табл. 2.

Кратність циркуляції розчину

$$
\begin{gathered}
f^{*}=\xi_{r}^{*} /\left(\xi_{r}^{*}-\xi_{a}^{*}\right) \\
f^{*}=64 /(64-57,3)=9,552 \text { кг } / \kappa г .
\end{gathered}
$$

Теплота теплообмінника

$$
q_{\mathrm{T}}^{*}=\left(f^{*}-1\right)\left(i_{4^{*}}-i_{8^{*}}\right)
$$

\begin{tabular}{|c|c|c|c|c|}
\hline $\begin{array}{c}\text { Стан } \\
\text { речовини }\end{array}$ & $\begin{array}{l}T, \\
\mathrm{~K}\end{array}$ & $\begin{array}{c}p, \\
\text { кПа }\end{array}$ & $\begin{array}{l}\xi \\
\%\end{array}$ & $\begin{array}{c}i, \\
\text { кДж/кг }\end{array}$ \\
\hline \multicolumn{5}{|c|}{ Рідина } \\
\hline $\begin{array}{l}\text { Вода після } \\
\text { конденсатора }\end{array}$ & $\begin{array}{l}T_{\mathrm{K}}=T_{3} \\
=307\end{array}$ & $\begin{array}{l}p_{\mathrm{K}}= \\
5,45\end{array}$ & $\xi=0$ & $i_{\mathrm{s}}=561,1$ \\
\hline $\begin{array}{l}\text { Розчин: } \\
\text { міцний після } \\
\text { генератора }\end{array}$ & $\begin{array}{l}T_{4}= \\
358\end{array}$ & $\begin{array}{l}p_{h}= \\
5,45\end{array}$ & $\begin{array}{c}\xi_{r}^{*}= \\
64\end{array}$ & $\begin{array}{c}i_{4 *}= \\
353,8\end{array}$ \\
\hline $\begin{array}{l}\text { слабкий після } \\
\text { абсорбера }\end{array}$ & $\begin{array}{l}T_{2}= \\
307\end{array}$ & $\begin{array}{l}p_{a}= \\
0,83\end{array}$ & $\begin{array}{l}\xi_{\mathrm{a}}{ }^{*}= \\
57,3\end{array}$ & $\begin{array}{c}i_{2 *}= \\
251,22\end{array}$ \\
\hline $\begin{array}{l}\text { міцний після } \\
\text { теплообмінни- } \\
\text { ка }\end{array}$ & $\begin{array}{l}T_{8}= \\
307\end{array}$ & $\begin{array}{l}p_{h}= \\
5,45\end{array}$ & $\begin{array}{c}\xi_{r}^{*}= \\
64\end{array}$ & $\begin{array}{l}i_{8 *}= \\
262,9\end{array}$ \\
\hline $\begin{array}{l}\text { Вода у ви- } \\
\text { парнику }\end{array}$ & $\begin{array}{l}T_{0}=T_{1} \\
=277\end{array}$ & $\begin{array}{l}p_{0}= \\
0,83\end{array}$ & $\xi=0$ & $i_{1}=435,5$ \\
\hline \multicolumn{5}{|c|}{ Пара } \\
\hline $\begin{array}{l}\text { Після випар- } \\
\text { ника }\end{array}$ & $\begin{array}{l}T_{1}=T_{0} \\
=277\end{array}$ & $\begin{array}{l}p_{0}= \\
0,83\end{array}$ & $\xi=$ & $\begin{array}{c}i_{1^{\prime}}= \\
2914,2\end{array}$ \\
\hline
\end{tabular}

$$
q_{\mathrm{T}}^{*}=(9,552-1)(353,8-262,9)=777,38 \text { кДж/кг. }
$$

Таблиця 2 - Параметри вузлових точок 

мінника

Ентальпія слабкого розчину після теплооб-

$$
\begin{gathered}
i_{7^{*}}=i_{2^{*}}+q_{\mathrm{T}}^{*} / f^{*} \\
i_{7^{*}}=251,22+777,38 / 9,552=332,6 \text { кДж/кг. }
\end{gathered}
$$

За значенням $i_{7^{*}}=332,6$ кДж/кг при $\xi_{a}{ }^{*}=57,3 \%$ по $\xi-i$ діаграмі визначають положення точки $7^{*}$ та температуру слабкого розчину на виході $з$ теплообмінника $T_{7}=349 \mathrm{~K}$.

У зв'язку з тим, що слабкий розчин на вході в генератор перегрітий, у генераторі здійснюється спочатку адіабатно-ізобарний процес десорбції $\left(7^{*}-5^{*}\right)$, внаслідок чого концентрація розчину збільшується, а температура його знижується до рівноважної $T_{5}$. Температура $T_{5}$ вище рівноважної $T_{6}$ при відомих $\xi_{a}^{*}, p_{h}: T_{5}=345 \mathrm{~K}, T_{6}=343,5 \mathrm{~K}$.

Середня температура розчину, що кипить у генераторі,

$$
\begin{gathered}
T_{\mathrm{p}}=\left(T_{4}+T_{5}\right) / 2 \\
T_{\mathrm{p}}=(358+345) / 2=351,5 \mathrm{~K} .
\end{gathered}
$$

Концентрація розчину, що відповідає темпеpaтурі $T_{\mathrm{p}}$ (точка $\left.10^{*}\right), \xi_{\mathrm{p}}=60,8 \%$.

Ентальпія перегрітої пари на виході 3 генератора визначається за $\xi-i$ діаграмою при відомих $p_{h}$ i $\xi_{\mathrm{p}}: i_{3},=3064$ кДж/кг.

Теплота генератора

$$
q_{h}=i_{3^{\prime}}+\left(f^{*}-1\right) i_{4^{*}}-f^{*} i_{7^{*}}
$$

$q_{h}=3064+(9,552-1) 353,8-9,552 \cdot 332,6=2912,7$ кДж/кг.

Теплота випарника

$$
\begin{gathered}
q_{0}=i_{1^{\prime}}-i_{3} \\
q_{0}=2914,2-561,1=2353,1 \text { кДж/кг. }
\end{gathered}
$$

Теплота конденсатора

$$
\begin{gathered}
q_{\mathrm{K}}=i_{3^{\prime}}-i_{3} \\
q_{\mathrm{K}}=3064-561,1=2502,9 \text { кДж/кг. }
\end{gathered}
$$

Теплота абсорбера

$$
q_{\mathrm{a}}=i_{1^{\prime}}+\left(f^{*}-1\right) i_{8^{*}}-f^{*} i_{2^{*}}
$$

$q_{\mathrm{a}}=2914,2+(9,552-1) 262,9-9,552 \cdot 251,22=2762,9$ кДж $/$ кг.

Абсорбція складається 3 двох процесів: адіабатно-ізобарного $\left(8^{*}-9^{*}\right)$ та ізобарного $\left(9^{*}-2^{*}\right)$.

Теплота, що підведена

$$
\sum q_{\text {підв }}=q_{h}+q_{0}
$$

$\sum q_{\text {підв }}=2912,7+2353,1=5265,8$ кДж/кг.

Теплота, що відведена

$$
\sum q_{\text {відв }}=q_{\mathrm{K}}+q_{\mathrm{a}}
$$

$\sum q_{\text {відв }}=2502,9+2762,9=5265,8$ кДж/кг.

Тепловий баланс

$$
\sum q_{\text {підв }}=\sum q_{\text {відв }}=5265,8 \text { кДж/кг. }
$$

Тепловий коефіцієнт

$$
\begin{gathered}
\xi^{*}=q_{0} / q_{h} \\
\xi^{*}=2353,1 / 2912,7=0,808 .
\end{gathered}
$$

\section{4. Розрахунок АВXM [5].}

Початкові дані:

- Тиск насиченої гріючої водяної пари $p_{h}=0,792 \mathrm{MПа}$

- Температура охолоджувальної води $T_{w 1}=298 \mathrm{~K}$;

- Температура охолоджуваного розсолу $T_{s 2}=258 \mathrm{~K}$

- Температура гріючої пари при $p_{h}=0,792 \mathrm{MПа} \mathrm{-}$ $T_{h}=443 \mathrm{~K}$;

Розглянемо цикл та теплові потоки абсорбційної водоаміачної холодильної машини 3 теплообмінником розчинів, ректифікатором та дефлегматором, що охолоджується водою (рис. 7).

Параметри вузлових точок циклу наведено у таблиці 3

Після ректифікації пари в ректифікаційній колоні і дефлегматорі температура пари на виході 3 дефлегматора приймається рівною $T_{e^{\prime}}=T_{\mathrm{\kappa}}+\Delta T=$ $303,3+9,7=313$ К. Тоді концентрація пари $\xi_{e^{\prime}}=0,9959$ кг/кг. Останню визначають за таблицями термодинамічних параметрів рівноважних фаз водоаміачного розчину [6] та розрахункових залежностей [7]. 


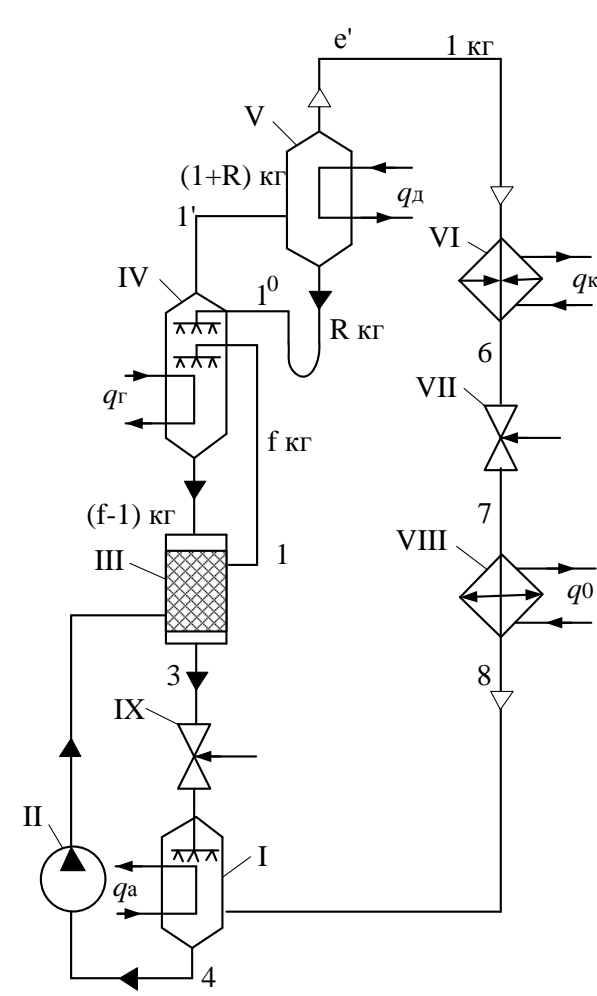

a)

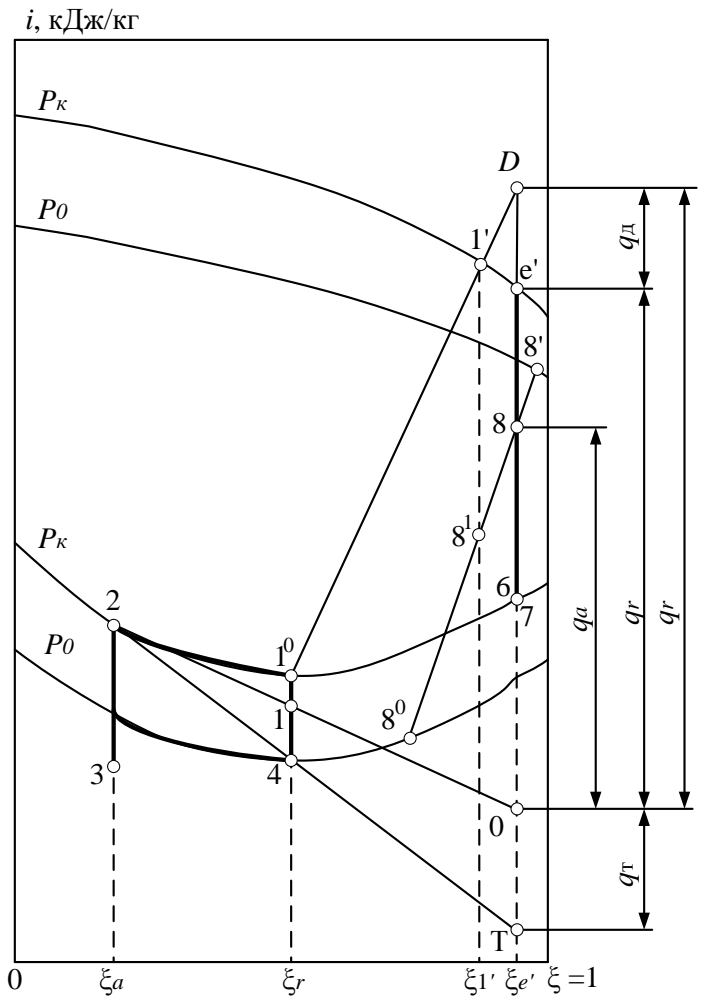

б)

Рисунок 7-Абсорбиійна водоаміачна холодильна машина з теплообмінником, ректифікатором та водяним дефлегматором: а - схема машини; б - прочеси в $\xi$-і діаграмі;

I - Абсорбер; II - насос мічного розчину; III - теплообмінник розчинів; IV - генератор із ректифікатором; V-дефлегматор; VI-конденсатор; VII - дросельний вентиль холодоагенту; VIII - випарник; IX - дросельний вентиль розчину

Таблиця 3 - Параметри вузлових точок

\begin{tabular}{|c|c|c|c|c|}
\hline Стан речовини & $T, \mathrm{~K}$ & $p$, МПа & $\xi, \kappa г / \kappa \Gamma$ & $i$, кДж/кг \\
\hline \multicolumn{5}{|c|}{ Рідина } \\
\hline після генератора & $T_{2}=433$ & $p_{\mathrm{K}}=1,17684$ & $\xi_{a}=0,0904$ & $i_{2}=614,23$ \\
\hline після абсорбера & $T_{4}=303,3$ & $p_{0}=0,176526$ & $\xi_{r}=0,3676$ & $i_{4}=-111,46$ \\
\hline після конденсатора & $T_{6}=303,3$ & $p_{\mathrm{K}}=1,17684$ & $\xi_{e^{\prime}}=0,9959$ & $i_{6}=141,87$ \\
\hline на початку кипіння (міцний розчин) & $T_{1^{\circ}}=367,3$ & $p_{\mathrm{K}}=1,17684$ & $\xi_{r}=0,3676$ & $i_{1^{\circ}}=191,49$ \\
\hline $\begin{array}{l}\text { після теплообмінника (слабкий роз- } \\
\text { чин) }\end{array}$ & $T_{2}=308,3$ & $p_{\mathrm{\kappa}}=1,17684$ & $\xi_{a}=0,0904$ & $i_{2}=73,33$ \\
\hline \multicolumn{5}{|c|}{ Пара } \\
\hline після генератора & $T_{1^{\prime}}=367,3$ & $p_{\mathrm{K}}=1,17684$ & $\xi_{1^{\prime}}=0,9478$ & $i_{1^{\prime}}=1529,16$ \\
\hline після дефлегматора & $T_{i^{\prime}}=313$ & $p_{\mathrm{K}}=1,17684$ & $\xi_{e^{\prime}}=0,9959$ & $i_{e^{\prime}}=1323,59$ \\
\hline $\begin{array}{l}\text { Насичена за вищої температури } \\
\text { кипіння у випарнику }\end{array}$ & $T_{8^{\prime}}=255$ & $p_{0}=0,176526$ & $\xi_{\mathrm{H}}=1$ & $i_{\mathrm{H}}=1245,42$ \\
\hline
\end{tabular}

Термодинамічні властивості водоаміачного розчину розраховані відповідно до довідкових даних [6].

У зв'язку з вищою концентрацією розчину, що надходить у випарник, тиск кипіння у випарнику приймається рівним $p_{0}=p_{0}^{\prime}-\Delta p_{0}=0,190314-$ $-0,013888=0,176526$ МПа.

Вища температура кипіння розчину у випар- нику приймається рівною $T_{8}=T_{2}+\Delta T=$ $=253+2=255 \mathrm{~K}$

Кратність циркуляції розчину

$$
f=\left(\xi_{e^{\prime}}-\xi_{a}\right) /\left(\xi_{r}-\xi_{a}\right)
$$


$f=(0,9959-0,0904) /(0,3676-0,0904)=3,267$ кг/кг.

Маса флегми, що утворюється в дефлегматорі,

$$
R=\left(\xi_{e^{\prime}}-\xi_{1^{\prime}}\right) /\left(\xi_{1^{\prime}}-\xi_{r}\right)
$$

$R=(0,9959-0,9478) /(0,9478-0,3676)=0,0829$ кг/кг.

Теплота дефлегматора

$$
\begin{gathered}
q_{\text {д }}=(1+R) i_{1^{\prime}}-i_{e^{\prime}}-R i_{1 \circ} \\
q_{\text {д }}=(1+0,0829) 1529,16-1323,59- \\
-0,0829 \cdot 191,49=316,47 \text { кДж/кг. }
\end{gathered}
$$

Теплота теплообмінника

$$
q_{\mathrm{T}}=(f-1)\left(i_{2}-i_{3}\right)
$$

$q_{\mathrm{T}}=(3,267-1)(614,23-73,33)=1226,22$ кДж/кг.

Стан міцного розчину після теплообмінника

$$
i_{1}=i_{4}+q_{\mathrm{T}} / f
$$

$i_{1}=-111,46+1226,22 / 3,267=263,88$ кДж/кг.

Згідно з графіком $T=\varphi(i)$ при $\xi_{r}=0,3676$ та $p_{\mathrm{\kappa}}=1,17684$ МПа знаходять температуру міцного розчину після теплообмінника $T_{1}=371,6 \mathrm{~K}$.

Теплота генератора

$$
q_{\text {厂 }}=i_{e^{\prime}}-i_{2}+f\left(i_{2}-i_{1}\right)+q_{\text {д }}
$$

$q_{\mathrm{r}}=1323,59-614,23+3,267(614,23-263,88)+$

$+316,47=2170,42$ кДж/кг.

Теплота конденсатора

$$
\begin{gathered}
q_{\mathrm{\kappa}}=i_{e^{\prime}}-i_{6} \\
q_{\mathrm{\kappa}}=1323,59-141,87=1181,72 \text { кДж/кг. }
\end{gathered}
$$

Теплота випарника

$$
\begin{gathered}
q_{0}=i_{8}-i_{6} \\
q_{0}=1177,65-141,87=1181,72 \text { кДж/кг. }
\end{gathered}
$$

Теплота абсорбера

$$
q_{\mathrm{a}}=i_{8}-i_{3}+f\left(i_{3}-i_{4}\right)
$$

$q_{\mathrm{a}}=1177,65-73,33+3,267(73,33+111,46)=$

$=1708,03$ кДж/кг.
Тепловий баланс:

Теплота, що підведена

$$
\sum q_{\text {підв }}=q_{\text {г }}+q_{0}
$$

$\sum q_{\text {підв }}=2170,42+1035,78=3206,2$ кДж/кг.

Теплота, що відведена

$$
\begin{gathered}
\sum q_{\text {відв }}=q_{\mathrm{\kappa}}+q_{\mathrm{a}}+q_{\text {д }} \\
\sum q_{\text {відв }}=1181,72+1708,3+316,47=3206,22 \text { кДж/кг. }
\end{gathered}
$$

Тепловий коефіцієнт

$$
\begin{gathered}
\xi=q_{0} / q_{\text {Г }} \\
\xi=1035,78 / 2170,42=0,477 .
\end{gathered}
$$

\section{5. Розрахунок TOO}

Проводимо розрахунок теплообмінника-охолоджувача (ТОО) газу перед стисненням.

Оцінимо теплове навантаження на генератор ABХМ з боку потоку вихлопних газів газотурбінного двигуна ДН-70.

$$
Q_{\Gamma}=G_{\Gamma} C_{\mathrm{P \Gamma}}\left(t^{\prime}-t^{\prime \prime}\right),
$$

де $G_{\Gamma}$ - витрата продуктів згоряння, рівний 36,8 кг/с; $C_{\mathrm{P \Gamma}}-$ масова теплоємність продуктів згоряння, що дорівнює 1,15 кДж/кгК [6];

$t^{\prime}, t^{\prime \prime}$ - температури продуктів згоряння на вході $\left(t^{\prime}=550^{\circ} \mathrm{C}\right)$ та виході, відповідно.

Приймемо температуру $t^{\prime \prime}=400{ }^{\circ} \mathrm{C}$, що відповідає ККД процесу теплообміну між потоком продуктів згоряння та стінкою генератора 40 \%.

Тоді:

$$
Q_{\Gamma}=36,8 \cdot 1,15(550-400)=6348 \text { кВт. }
$$

Вибираємо під теплове навантаження ABХМ європейського виробництва PED 3 холодопродуктивністю 2850 кВт, тепловим навантаженням генератора 5100 кВт, температурою випаровування $0{ }^{\circ} \mathrm{C}$.

При заданій об'ємній витраті газу $181 \mathrm{~m}^{3} / \mathrm{xв}$ (масова витрата 144 кг/с) і обраній АВХМ є можливість охолодити вхідний потік газу на $16{ }^{\circ} \mathrm{C}$, тобто від $300 \mathrm{~K}\left(27^{\circ} \mathrm{C}\right)$ до $284\left(11^{\circ} \mathrm{C}\right)$. Перепад температур на холодному кінці ТОО складе $\Delta t=11^{\circ} \mathrm{C}$. 
Приймемо аналогічний перепад i на «гарячому» кінці ТОО, тобто розсіл нагріватиметься до $289 \mathrm{~K}\left(26^{\circ} \mathrm{C}\right)$.

Масова витрата розсолу АВХМ становитиме $84 \mathrm{\kappa г} / \mathrm{c}$.

Вибираємо елемент конструкції ТОО 3 коаксіальним розташуванням ребер з боку газового потоку (рис. 8).

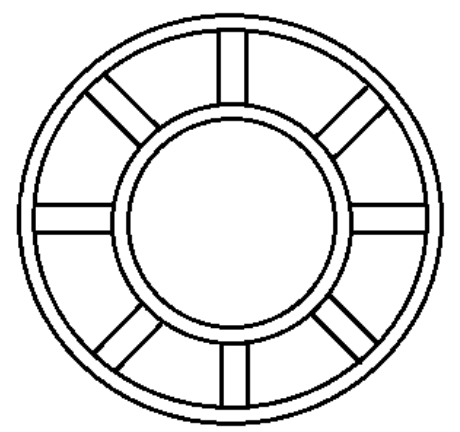

Рисунок 8 - Схема елемента ТОО

Внутрішня труба має діаметр 200 м, зовнішня труба - 600 мм.

Висота ребра - 200 мм. При ефективності алюмінієвого ребра $E=0,85$, його товщина становить 10 мм. Число ребер - 22 шт. Крок ребра 20 мм.

Тоді площа ребер на 1 м ТОО:

$$
F_{\mathrm{p}}=1(0,2 \cdot 2+0,01) 22=9,02 \mathrm{M}^{2} .
$$

Площа міжреберного простору ТОО:

$$
F_{\mathrm{c}}=0,01 \cdot 1 \cdot 21=0,21 \mathrm{M}^{2} .
$$

Сумарна площа поверхні теплообміну з боку газу:

$$
F_{\mathrm{pc}}=F_{\mathrm{p}}+F_{\mathrm{c}}=9,02+0,21=9,33 \mathrm{M}^{2} .
$$

Оцінимо коефіцієнт теплообміну газу $\alpha_{\mathrm{p}}=\alpha_{\mathrm{c}}=$ $=400 \mathrm{BT} /\left(\mathrm{m}^{2} \cdot \mathrm{K}\right)$. Тоді наведений коефіцієнт теплообміну

$$
\begin{gathered}
\alpha_{\text {нав }}=\alpha_{\mathrm{p}} E \frac{F_{\mathrm{p}}}{F_{\mathrm{pc}}}+\alpha_{\mathrm{c}} \frac{F_{\mathrm{c}}}{F_{\mathrm{pc}}} \\
\alpha_{\text {нав }}=400 \cdot 0,85 \cdot \frac{9,02}{9,33}+400 \frac{0,21}{9,33}=335 \mathrm{BT} /\left(\mathrm{M}^{2} \cdot \mathrm{K}\right)
\end{gathered}
$$

Проводимо розрахунок теплового навантаження 1 м за рівнянням теплопередавання для реб- ристої поверхні:

$$
Q=\frac{\Delta t}{\frac{1}{\lambda_{1} F_{1}}+\frac{\delta}{\lambda F_{1}}+\frac{1}{\lambda_{\text {нав }} F_{\mathrm{pc}}}}
$$

де $\lambda_{1}$ - коефіцієнт теплообміну з боку розсолу, приймаємо рівним $5000 \mathrm{BT} /\left(\mathrm{m}^{2} \cdot \mathrm{K}\right) ; \delta=4$ мм; $\lambda=200 \mathrm{BT} /($ м $\cdot \mathrm{K}) ; F_{1}=\pi \cdot 0,20 \cdot 1=6,28 \mathrm{~m}^{2}$. Тоді:

$$
Q=\frac{9}{\frac{1}{500 \cdot 6,28}+\frac{0,004}{200 \cdot 6,28}+\frac{1}{335 \cdot 9,33}}=27,2 \text { кВт. }
$$

Довжина ТОВ складе:

$$
l_{\mathrm{TOO}}=\frac{2850}{27,2} \approx 105 \mathrm{M}
$$

\section{6. Висновки}

1. Відповідно до розробленого алгоритму було виконано розрахунок нагнітача $\mathrm{H}-300-1,23$ для різних температур $(275,285,292,5$ та 300 К) природного газу перед компремуванням.

Показано, що:

a) починаючи $3300 \mathrm{~K}$ до $285 \mathrm{~K}$ має місце лінійне падіння індикаторної потужності стиснення, а в діапазоні 275-285 К падіння уповільнюється і переходить до асимптотичного;

б) у досліджуваному діапазоні температур газу перед компримуванням (275-300 К) має місце лінійне підвищення температур після стиснення, відповідно, від 290 К до 320 К;

в) використання штучного охолодження потоку газу перед всмоктуванням дасть економію витрати паливного газу: $836-757=79$ кг/год.

2. Виконано термодинамічний розрахунок циклів АБХМ та АВХМ. Показано, що, незважаючи на більш високий тепловий коефіцієнт у АБХМ $(0,808)$, слід вибрати АВХМ 3 тепловим коефіцієнтом 0,477, оскільки тільки АВХМ може забезпечити прийнятний рівень температур охолодження (258 К) природного газу перед компримуванням, на відміну від АБХМ з температурою охолодження 280 К. Вибрано АВХМ європейського виробництва PED 3 холодопродуктивністю 2850 кВт, тепловим навантаженням генератора 5100 кВт, температурою випаровування $0{ }^{\circ} \mathrm{C}$.

3. Виконано конструкторський (тепловий) роз- 
рахунок теплообмінника-охолоджувача природного газу перед стисненням у нагнітачі. Проведено розрахунок для конструкції ТОО з коаксіальним розташуванням ребер з боку газового потоку. Матеріал ребер - алюміній. Розрахункова довжина труби ТОО склала близько 105 м.

\section{Особистий внесок авторів CRediT}

Тітлов О.С.: концептуалізація, методологія, дослідження, написання - оригінальний проект, адміністрування. Бошкова І.Л.: перевірка, формальний аналіз, написання - огляд та редагування. Дорошенко В.М.: візуалізація, формальний аналіз, еволюція загальних цілей та завдань. Світлицький В.М.: візуалізація, програмне забезпечення. Сагала Т.А.: верифікація, дослідження. Морозов О.А.: візуалізація, програмне забезпечення.

\section{Література}

1. Середюк М. Д. Проектування та експлуатація нафтопродуктопроводів. - Івано-Франківськ: ІФНТУНГ, 2002. - 282 с.

2. Titlov O., Vasyliv O., Sahala T., Bilenko N. Evaluation of the prospects for preliminary cooling of natural gas on main pipelines before compression through the discharge of exhaust heat of gas-turbine units // EUREKA: Physics and Engineering. - 2019. № 5. - P. 47-55.

3. Морозюк Л.И. Теплоиспользующие холодильные машины - пути развития и совершенствования // Холодильна техніка та технологія. - 2014. № 5. - С.23-29.

4. Титлов А. С., Сагала Т. А., Артюх В. Н., Дьяченко Т. В. Анализ перспектив использования пароэжекторной и абсорбционной холодильных установок для охлаждения технологического газа и получения жидкого углеводородного топлива // Холодильная техника и технология. - 2017. - № 6. - С.11-18.

5. Галимова Л.В. Абсорбционные холодильные машины и тепловые насосы. - Астрахань: Изд-во АГТУ, 1997. - 226 с.

6. Богданов С. Н, Бурцев С.И., Иванов О.П., Куприянова А.В. Справочник. Свойства веществ. Холодильная техника. - СПб.: СПбГАХПТ, 1999. $-320 \mathrm{c}$.

7. Осадчук Е.А., Титлов А.С. Аналитические зависимости для расчета термодинамических параметров и теплофизических свойств водоаммиачного раствора // Наукові праці ОНАХТ. - 2011. - № 39. - T.1. - C. 178-182.

Отримана в редакції 14.09.2021, прийнята до друку 01.10.2021

\title{
Analysis of energy prospects for natural gas cooling in main gas pipelines using absorption refrigeration machines
}

\author{
Oleksandr Titlov $^{\bowtie I}$, Iryna Boshkova ${ }^{2}$, Volodymyr Doroshenko $^{3}$, Viktor Svitlytskyi ${ }^{4}$, Tetiana Sahala $^{5}$, Oleksii \\ Morozov $^{6}$ \\ ${ }^{1-6}$ Odessa National Academy of Food Technologies, 112 Kanatna str., Odessa, 65039, Ukraine \\ $\triangle$ e-mail: ${ }^{1}$ titlov1959@gmail.com \\ ORCID: ${ }^{1}$ https://orcid.org/0000-0003-1908-5713; ${ }^{2}$ https://orcid.org/0000-0001-5989-9223; \\ ${ }^{3}$ https://orcid.org/0000-0003-3408-6124; ${ }^{4}$ https://orcid.org/0000-0003-1908-5713; \\ ${ }^{5}$ https://orcid.org/0000-0003-3569-7920; ${ }^{6}$ https://orcid.org/0000-0001-5923-2584
}

For the transportation of natural gas by main pipelines at compressor stations (CS) gas pumping units (GPU) are installed, the energy carrier for which, in most cases, is the transported natural gas. 0.5 ... 1.5\% of the transported gas is consumed (burned) on the GPU drive. For the current economic situation in the gas market of Ukraine, the daily reduction of operating costs in typical main gas pipelines with a decrease in gas temperature before compression in the GPU by $20 \mathrm{~K}$ is from 1800 to $3360 \$$. One of the promising ways to reduce operating losses in the main gas pipelines is the pre-cooling of compressed gas using heat-using absorption refrigeration machines (ARM), which utilize the waste heat of spent combustion products of gas pumping units. According to the developed algorithm, the supercharger was calculated for different natural gas temperatures before compression. It is shown that the use of a typical main gas pipeline for artificial 
cooling of the gas flow before suction will save fuel gas consumption of $79 \mathrm{~kg} / \mathrm{h}$. Thermodynamic calculation of ARM cycles of different types is performed. It is shown that despite the higher thermal coefficient in lithium bromide ARM (0.808), it is necessary to choose ammonia ARM with a thermal coefficient of 0.477, because only ammonia ARM can provide an acceptable level of cooling temperatures $(258 \mathrm{~K})$ of natural gas before compression. with a cooling temperature not exceeding $280 \mathrm{~K}$. The design (thermal) calculation of the heat exchanger-cooler (HEC) of natural gas before compression in the supercharger is performed. The design of the heat exchanger with the coaxial arrangement of the fins on the gas flow side is calculated. The material of the ribs is aluminum.

Keywords: Absorption refrigeration machines; Waste heat; Energy efficiency; Compressor stations; Precooling of natural gas; Main gas pipelines

\section{References}

1. Serediuk, M.D. (2002) Design and operation of oil pipelines. Ivano-Frankivsk: IFNTUNG, 282.

2. Titlov, O., Vasyliv, O., Sahala, T., Bilenko, N. (2019) Evaluation of the prospects for preliminary cooling of natural gas on main pipelines before compression through the discharge of exhaust heat of gas-turbine units. EUREKA: Physics and Engineering, 5, 47-55.

3. Morozyuk, L.I. (2014) Heat-using refrigerating machines - ways of development and improvement. Kholodilnaya Tekhnika i Tekhnologiya, 5, 23-29.

4. Titlov, O.S., Sahala, T.A, Artiukh, V.N., Diachenko, T.V. (2017) Analysis of the prospects for the use of steam jet and absorption refrigeration units for cooling process gas and production of liquid hydro- carbon fuel. Kholodilnaya Tekhnika i Tekhnologiya, 6, 11-18.

5. Galimova, L.V. (1997) Absorption refrigeration machines and heat pumps. Astrakhan: Publishing house of ASTU, 226.

6. Bogdanov, S.N, Burtsev, S.I., Ivanov, O.P., Kupriyanova, A.V. (1999) Directory. Properties of substances. Refrigeration equipment. SPb.: SPbGAKhPT, 320.

7. Osadchuk, E.A., Titlov, O.S. (2011) Analytical dependences for calculating thermodynamic parameters and thermophysical properties of ammonia-water solution. Naukovi pratsi ONAFT, 39, 1, 178-182.

Received 24 September 2021

Approved 01 October 2021

Available in Internet 15 October 2021 